\title{
FENOMENA "KUPU-KUPU ABU-ABU" SEBAGAI BENTUK PENYIMPANGAN SOSIAL PADA KALANGAN REMAJA DI CIANJUR
}

\author{
${ }^{1}$ Andika Prabowo, ${ }^{2}$ Dasim Budimansyah dan ${ }^{3}$ Wilodati \\ ${ }^{1}$ Pengajar Bimbingan Belajar Ganesha Operation Cinajur \\ ${ }^{2}$ Dosen Prodi Pendidikan Sosiologi FPIPS Universitas Pendidikan Indonesia \\ ${ }^{3}$ Dosen Prodi Pendidikan Sosiologi FPIPS Universitas Pendidikan Indonesia \\ E-mail : prabowoandika@gmail.com
}

\begin{abstract}
ABSTRAK
Penelitian ini mengupas secara mendalam mengenai fenomena kupukupu abu-abu yang menjangkit beberapa remaja siswi di Cianjur. Kupukupu abu-abu merupakan sebutan bagi gadis remaja berstatus pelajar yang memiliki perilaku menyimpang dimana mereka sering melakukan hubungan seks diluar nikah dengan kekasihnya ataupun laki-laki yang baru dikenal tanpa menuntut bayaran. Melakukan hubungan seks atas dasar kesenangan menjadikannya pembeda antara kupu-kupu abu-abu dengan WTS (Wanita Tuna Susila) pada umumnya. Berbagai macam faktor melatarbelakangi dimulai dari rendahnya tingkat ekonomi, keluarga tidak harmonis, lingkungan, konsumsi minuman keras, hingga faktor paling mengerikan yaitu para pelaku memiliki kelainan seks yang disebut hypersexual. Maka dari itu gadis kupu-kupu abu-abu dalam melakukan hubungan seks tidak meminta bayaran karena yang mereka cari adalah kepuasan.
\end{abstract}

Kata Kunci : Penyimpangan Sosial, Kupu-kupu Abu-abu.

\section{PENDAHULUAN}

Masa remaja adalah masa-masa yang paling indah. Pencarian jati diri seseorang terjadi pada masa remaja. Bahkan banyak orang mengatakan bahwa remaja adalah tulang punggung sebuah negara. Statement demikian barangtentu benar karena remaja merupakan generasi penerus bangsa yang diharapkan dapat menggantikan generasi-generasi terdahulu dengan kualitas kinerja dan mental yang lebih baik. Di tangan remajalah tergenggam arah masa depan bangsa ini.

Namun melihat kondisi remaja saat ini, harapan remaja sebagai penerus bangsa yang menjadi salah satu penentu kualitas negara di masa yang akan datang sepertinya bertolak belakang dengan kenyataan yang ada. Perilaku nakal dan menyimpang di kalangan remaja saat ini cenderung mencapai titik kritis. Telah banyak remaja yang terjerumus ke dalam kehidupan yang dapat merusak masa depan. Memang, sebagai bagian dari masalah-masalah sosial yang ada, kenakalan anak-anak dan remaja merupakan masalah yang serius karena akan mengancam kehidupan suatu bangsa. Penyakit sosial anakanak dan remaja muncul sebagai akibat melemahnya pengertian dan kewaspadaan terhadap kebutuhan dan 
permasalahan usia anak itu sendiri. Sifat sulit diatur, berontak, merajuk, kumpul-kumpul, suka meniru, mulai jatuh cinta, hura-hura dan sebagainya, adalah rangkaian pola perilaku yang selalu muncul membayangi sisi kehidupan remaja.

Hal ini tidak lain dikarenakan remaja itu sendiri belum memiliki pendirian kuat atau bias dikatakan masih dalam masa labil. Dikatakan Soekanto (1982, hlm. 387) "Secara psikologis usia remaja merupakan umur yang dianggap gawat, karena yang bersangkutan sedang mencari identitasnya". Untuk itu diperlukan tokoh-tokoh ideal yang pola prilakunya terpuji untuk menjadi contoh bagi remaja karena remaja sangat rentan berperilaku menyimpang dari norma sosial yang ada di masyarakat.

Dalam rentang waktu kurang dari satu dasawarsa terakhir, kenakalan remaja semakin menunjukkan trend yang amat memprihatinkan. Kenakalan remaja yang diberitakan dalam berbagai forum dan media dianggap semakin membahayakan. Berbagai macam kenakalan remaja yang ditunjukkan akhir-akhir ini seperti perkelahian secara perorangan atau kelompok, tawuran pelajar, mabukmabukan, pemerasan, pencurian, perampokan, penganiayaan, penyalahgunaan narkoba, dan seks bebas pranikah kasusnya semakin menjamur.

Kemudian sebuah fenomena baru kini mulai muncul di Kota Cianjur. Beberapa remaja siswi yang masih duduk di bangku Sekolah Menengah Pertama (SMP) dan duduk di Sekolah Menengah Atas (SMA) yang seharusnya melakukan tugasnya dengan baik yaitu belajar dengan giat namun beberapa dari mereka ada yang menjajakan diri menjual jasa pemuas nafsu birahi kepada para pria hidung belang untuk mendapatkan uang jajan tambahan atau hanya sekedar dengan alasan suka sama suka.

Kupu-kupu abu-abu menjalankan aktivitas prostitusinya dengan beragam cara, ada yang terhimpun dalam sebuah kelompok yang dimotori oleh mucikari atau germo adapula yang bergerak secara individu. Hasil yang mereka dapat tidak lain digunakan untuk memenuhi kebutuhan hidupnya sendiri dan mereka melakukan hal ini tanpa sepengetahuan orangtuanya yang selama ini mendidiknya dengan penuh kasih sayang dan membimbing untuk menjadi pribadi yang baik.

Beragam motif yang melatarbelakangi seorang pelajar memilih untuk menjadi kupu-kupu abuabu, mulai dari tidak terpenuhinya kebutuhan akan kasih sayang kepada seorang anak di dalam keluarga karena broken home sehingga mencari pelarian kepada hal lain, memiliki sikap hidup hedon yang tidak disokong dengan keadaan ekonomi yang memadai sehingga mencari jalan pintas, dan seks bebas dikalangan pelajar yang membuat ada perasaan "terlanjur" terjerumus dalam dunia tersebut seperti yang disampaikan oleh salah seorang kupu-kupu abu-abu yang peneliti jumpai di Cianjur dengan sebutan Dinda (bukan nama sebenarnya, 18 tahun) kelas XI di salah satu Sekolah Menengah Atas, mengungkapan dirinya berasal dari keluarga broken home dan kini tinggal bersama ibunya dengan kondisi ekonomi yang menengah kebawah, merasa kondisi tersebut kurang bisa mencukupi hasrat gaya hidupnya, Dinda memutuskan untuk berpasangan dengan orang yang kaya agar bisa juga mencukupi hasrat gaya hidupnya. Mulai 
dari hal itu lah Dinda kini menjalankan aktivitas sebagai kupu-kupu abu-abu.

Para "kupu-kupu abu-abu" tidak memasang tarif tertentu atau mematok harga meskipun tujuan mereka adalah untuk mendapatkan keuntukan ekonomi namun mereka lebih mengutamakan negosiasi dengan priapria yang ingin menggunakan jasa tubuhnya agar mendapat kepuasan bersama dan untuk menghindari adanya salah satu pihak yang merasa dirugikan.

\section{METODE}

Penelitian ini menggunakan metode studi kasus karena dengan studi kasus peneliti dapat menyelidiki sebuah kasus atau fenomena dengan cermat dan mendapatkan informasi secara lengkap tehadap peristiwa atau fenomena yang sedang di teliti. Bungin (2012, hlm. 132) mendeskripsikan studi kasus sebagai "studi yang mendalam hanya pada satu kelompok orang atau peristiwa. Teknik ini hanyalah sebuah deskripsi terhadap individu. Sebuah studi kasus adalah sebuah puzzle yang harus dipecahkan" maksudnya ialah dalam metode studi kasus diharuskan memiliki informasi yang mendalam agar peneliti dapat memahami apa yang menjadi masalah terjadinya suatu kasus atau fenomena sosial.

Senada dengan penjelasan Bungin, Stake dalam Creswell (2010, hlm 20) menyatakan bahwa ;

Studi kasus merupakan strategi penelitian dimana di dalamnya peneliti menyelidiki secara cermat suatu program, peristiwa, aktifitas, proses, atau sekelompok individu. Kasus kasus dibatasi oleh waktu dan aktifitas, dan peneliti mengumpulkan informasi secara lengkap dengan menggunakan berbagai prosedur pengumpulan data berdasarkan waktu yang telah ditentukan.

Persiapan yang dilakukan peneliti dalam melakukan metode studi kasus harus dimulai dengan menguasai keterampilan yang memadai. Dengan menggunakan metode studi kasus peneliti berharap dapat mengidentifikasi permasalahan fenomena kupu-kupu abu-abu sebagai bentuk penyimpangan sosial pada remaja putri di Cianjur.

Teknik penelitian ini yaitu dengan mengguanakan observasi, wawancara, dan studi dokumentasi terhadap narasumber yaitu gadis kupu-kupu abuabu, germo dan laki-laki hidung belang. Maka trianggulasi data yang dipergunakan pada penelitian ini yaitu dengan cara trianggulasi sumber.

\section{HASIL DAN PEMBAHASAN}

Faktor Penyebab Remaja Melakukan Aktifitas sebagai Kupu-kupu Abuabu

Bebagai macam faktor yang melatarbelakangi seorang pelajar memilih untuk menjadi kupu-kupu abuabu, dimulai mulai dari tidak terpenuhinya kebutuhan akan kasih sayang kepada seorang anak di dalam keluarga karena broken home sehingga mencari pelarian kepada hal lain, memiliki sikap hidup hedon yang tidak disokong dengan keadaan ekonomi yang memadai sehingga mencari jalan pintas, dan seks bebas dikalangan pelajar yang membuat ada perasaan "terlanjur" terjerumus dalam dunia tersebut.

Seperti dikutip dalam Anwar (2010, hlm 355) menyatakan bahwa alasan wanita menjadi pelaku prostitusi adalah:

1. Karena tekanan ekonomi, seseorang tanpa pekerjaan 
tentunya akan tidak memperoleh penghasilan untuk nafkahnya. Maka terpaksalah mereka untuk hidup menjual diri sendiri dengan cara dan jalan yang paling mudah.

2. Karena tidak puas dengan posisi yang ada, walau sudah mepunyai pekerjaan tetapi belum puas karena tidak sanggup membeli barangbarang perhiasan yang bagus-bagus.

3. Karena kebodohan, tidak memiliki pendidikan atau intelegensi. Kita lihat wanitawanita pendidikan mempunyai intelegensi yang baik terdapat pada kalangan wanita "P" tingkat tinggi.

4. Karena ada cacat dalam jiwanya.

5. Karena sakit hati, ditinggal oleh suami atau suami beristri lagi sedangkan dia tidak rela dimadu.

6. Karena tidak puas dengan kehidupan seks, sebeb bersifat hypersexual.

Berdasarkan data hasil penelitian yang sudah dilakukan dapat dilihat bahwa Fenomena Kupu-kupu Abu-abu ini disebabkan oleh beberapa faktor, dari sekedar faktor ekonomi yang paling klasik, dorongan orang lain, pergaulan bebas, konsumsi alkohol bahkan sampai dengan faktor yang sangat mencengankan karena menurut data yang didapatkan peneliti para Kupukupu Abu-abu ini melakukan aktifitas tersebut atas dasar keinginan pribadi pelaku karena memiliki kecenderungan akan kebutuhan seks yang cukup tinggi atau disebut dengan istilah hypersexual oleh karena itu pelaku memiliki anggapan bahwa prilaku seks bebas adalah hal yang wajar ketika dilakukan.

Karena masa remaja adalah masa yang rentan maka tidak menutupi kemungkinan bahwa ada beberapa remaja yang terjerumus kedalam suatu tindak perilaku menyimpang seperti remaja kupu-kupu abu-abu dimana para remaja yang seharusnya duduk manis menerima permbelajaran dan menjadi anak baik sewajarnya pelajar namun apadaya ketika remaja kupukupu abu-abu ini melakukan perilaku seks bebas sebagai kebiasaannya. Dorongan seks atau yang sering disebut libido juga menghampiri tiaptiap individu di masa remajanya, dorongan ini adalah dorongan untuk melakukan suatu akrifitas seksual dengan lawan jenis seperti hubungan seks pada umumnya sebagai sarana pemuas nafsu seksnya sendiri namun hubungan seks hanya bisa dilakukan dengan cara ikatan perkawinan sah tetapi seseorang ketika remaja dirasa belum siap untuk berikrar dalam sebuah ikatan suci pernikahan maka dari itu dorongan tersebut tidak bisa tersalurkan dan menjadi suatu permasalahan yang dihadapi remaja, kemudian upaya yang dilakukan untuk memenuhi libido seks biasanya remaja melakukan perilaku-perilaku menyimpang seperti onani (bagi kaum laki-laki), menonton video porno, homoseksual, lesbian, dan pelacuran. Seperti dikatakan Willis (2012, hlm 26) "sering terjadi pula penyimpangan dalam mencari kepuasan seks antara lain dengan kegiatan onani, homoseksual, lesbianisme, pelacuran, pornografi, bestiality, grontoseksual, dan incest"

Perilaku seks bebas yang dilakukan kupu-kupu abu-abu didasari oleh faktor kenakalan dalam pergaulan karena menurut data yang diperoleh di lapangan berdasarkan hasil wawancara yang telah dilakukan terhadap kupu-kupu abu-abu tersebut bahwasalnya para kupu-kupu 
melakukan hubungan seks bebas karena pada saat memiliki kekasih mereka sering melakukan hubungan seks diluar nikah, atas dasar kepuasan seks yang didapatinya pelaku membuat perilaku seks bebas tersebut menjadi sebuah kebiasaan.

Kebiasaan yang dilakukan kupukupu abu-abu mulai meluas dalam artian para kupu-kupu abu-abu tidak hanya melakukan hubungan seks dengan kekasihnya saja melainkan dengan orang lain yang baru ia kenalpun para pelaku ini bisa melakukan hubungan seks diluar nikah karena kebutuhan seks yang membuatnya seperti itu. Menurut data yang peneliti temukan bahwasalnya kupu-kupu abu-abu ini tidak menuntut sebuah materi sebagai upah atas hubungan seks yang telah dilakukan akan tetapi hubungan seks diluar nikah tersebut dilakukan kupu-kupu abu-abu atas dasar suka sama suka dan mereka lebih mementingkan kepuasan seks yang didapatkan dengan kata lain kupu-kupu abu-abu ini adalah seseorang dengan kelainan seks yang disebut hypersexsual.

\section{Kupu-kupu Abu-abu dalam Menjalankan Proses Prostitusinya}

Gadis kupu-kupu abu-abu adalah remaja berstatus pelajar yang masih berusia kurang lebih 15-18 tahun selain menjalankan aktifitas sebagai pelajar pada umumnya para kupu-kupu abuabu ini memiliki kebiasaan buruk diluar sekolah dan kebiasaan tersebut adalah perilaku seks bebas yang dilakukan dengan siapa saja yang ia kehendaki.

Menurut data yang didapatkan peneliti berdasarkan hasil observasi dan wawancara yang sudah dilakukan peneliti mendapati bahwa para kupukupu abu-abu menjalankan aktifitasnya sangat rapih dan tersembunyi karena mereka tidak menjajakan diri layaknya WTS di lokalisasi prostitusi yang memiliki tempat menjajakan diri dan meawarkan dirinya kepada laki-laki hidung belang untuk mendapatkan materi dalam bentuk uang atas service yang sudah diberikannya. Lebih lanjut kupu-kupu abu-abu hanya dapat diketahui oleh laki-laki hidung belang yang pernah berhubungan seks dengannya saja melalui pembicaraan dari mulut ke mulut para laki-laki hidung belang maka didapatkanlah kupu-kupu abu-abu tersebut. Tidak ada cara lain untuk mendapatkan kupu-kupu abuabu ini karena mereka disebut independent atau melakukan aktifitasnya sendiri tanpa melibatkan orang lain dalam prosesnya.

Proses menjalankan kebiasaan buruknya ini para pelaku kupu-kupu abu-abu enggan untuk disebut sebagai WTS atau pelacur karena dirinya merasa perilaku yang ia lakukan tidak didasari dengan pengambilan untung dalam bentuk uang melainkan hanya menginginkan kebutuhan seksualnya bisa terpenuhi. Lebih lanjut hubungan seks bebas yang dilakukan kupu-kupu abu-abu ini dilakukan di waktu jam sekolah sudah selesai antara lain pada pukul 15.00 sore sampai dengan pukul 20.00 malam karena mereka tidak ingin kebiasaan buruknya ini diketahu oleh orang tuannya atau orang lain maka dari itu ia keluar rumahpun dengan jam yang sewajarnya. Namun ketika di sekolah tidak ada kegiatan belajar ia membolos untuk mengikuti ajakan kencan dari laki-laki hidung belang.

Karena esensi dari gadis kupukupu abu-abu ini bukanlah berbentuk materi maka dari itu gadis kupu-kupu abu-abu sangan selektif untuk memilah dan memilih terhadap laki-laki hidung belang yang hendak mengencaninya dan kriterianya pun tidak lain adalah 
berpenampilan menarik bagi laki-laki tersebut atau tampan dan memiliki kendaraan yang pantas atau bagus.

Lebih lanjut dalam kencan yang dilakukan gadis kupu-kupu abu-abu ini tidaklah seperti proses WTS dan lakilaki hidung belang di lokalisasi karena hal tersebut dilakukan dengan wanita yang berperan lebih aktif untuk menggoda laki-laki agar dapat mengencaninya. Hal ini senada dengan pendapat Kartono (1981, hlm 239) yang menyatakan bahwa ciri pelaku prostirusi diantaranya "cantik, ayu, rupawan, manis, aktraktif, menarik, baik wajah maupun tubuhnya. Bisa merangsang selera seks kaum pria". Berbeda dengan kupu-kupu abu-abu yang tidak menawarkan diri melainkan merekalah yang dicari dan diberi bujuk rayu sebagai usaha laki-laki hidung belang untuk dapat mengencainya dan ketika bujuk rayu itu telah dilontarkan oleh laki-laki hidung belang para gadis kupu-kupu tidak langsung menhendaki ajakan laki-laki tersebut melainkan keriteria yang telah dimiliki gadis tersebut harus tercapai oleh lalki-laki hidung belang itu untuk dapat mengencaninya.

Kupu-kupu abu-abu tidak memiliki tempat-tempat tertentu untuk berhubungan seks secara bebas karena mereka tidak seperti WTS yang sudah pasti memiliki tempat-tempat khusus untuk berhubungan seks seperti para germo yang telah menyediakan kamar-kamar khusus dalam rumah bordilnya. Namun untuk kupu-kupu abu-abu tersebut menyerahkan tempat terhadap laki-laki hidung belang yang mengajak kencan dan biasanya hubungan seks itu dilakukan di tempat laki-laki hidung belang tersebut seperti di kost-kostan, motel, atau bahkan rumah laki-laki tersebut.

\section{Dampak bagi Remaja yang Menjalankan Aktifitas Sebagai Kupu- kupu Abu-abu}

Tindak perilaku seks bebas yang dilakukan gadis kupu-kupu abu-abu ini memang dirasa menyenangkan bagi para pelakunya karena mereka merasa bahwa dengan seks bebas libido seksnya bisa tersalurkan. Kenikmatan duniawi menutup mata para pelaku kupu-kupu abu-abu dari dampak yang bisa diakibatkan karena kebiasaan buruknya ini namun atas dasar kenikmatan hidup mereka mengenyampingkan dampak-dampak yang bisa terjadi dari hubungan seks secara bebas.

Menurut data yang peneliti dapat dari penelitian ada beberapa dampak yang menghinggapi para gadis kupukupu abu-abu maupun para laki-laki hidung belang sebagai pengguna jasa seks dari kupu-kupu abu-abu tersebut. Dampak dari perilaku menyimpang tersebut disinggung pelaku adalah terjangkitnya suatu penyakit kelamin yang ia tidak mengetahui apa namanya namun jelasnya terasa nyeri pada alat kelamin gadis kupu-kupu abu-abu tersebut dengan ciri bibir vagina yang membengkak dan memerah, lecetlecet, sampai pada penyakit gonorrhoe atau kencing nanah. Seperti dikutip dalam Kartono (2009, hlm 249) memaparkan beberapa akibat dari pelacuran, diantaranya ialah:

1. Menimbulkan dan menyebarluaskan penyakit kelamin dan kulit. Penyakit yang paling banyak terdapat ialah syphilis dan gonorrhoe (kencing nanah).

2. Merusak sendi-sendi kehidupan keluarga.

3. Mendemoralisasi atau memberikan demoralisasi kepada 
lingkungan khususnya anakanak muda remaja pada masa puber dan adolesensi.

4. Berkorelasi dengan kriminalitas dan kecanduan bahan-bahan narkotika (ganja, morfin, hereoin, dan lain-lain)

5. Merusak sendi-sendi moral, susila, hukum, dan agama.

6. Adanya pengeksploitasian manusia oleh manusia lain.

7. Bisa menyebabkan terjadinya disfungsi seksual, misalnya impotensi, anorgasme, nymfomania, satiriasis, ejakulasi prematur yaitu pembuangan sperma sebelum zakar melakukan penetrasi dalam vagina atau liang sanggama, dan lain-lain.

Rasa sakit yang dirasa para gadis kupu-kupu abu-abu tersebut tentunya mengganggu dan cukup menyulitkan dalam menjalani aktifitas sehari-hari ketika terserang penyakit. Bukan berarti para gadis kupu-kupu abu-abu ini tidak menyadari akan adanya dampak yang akan ditimbulkan namun sebuah kenikmatan dalam hubungan seks membutakan mereka dari dampakdampak yang diakibatkan hubungan seks bebas tersebut

Lebih lanjut tidak hanya dampak penyakit yang didapatkan gadis kupukupu abu-abu namun dampak atau sanksi sosialpun didapatkannya. Sanksi sosial ini berupa pengucilan yang didapat gadis kupu-kupu abu-abu atas perilakunya dari teman-teman sepergaulannya yang telah mengetahui kebiasaan buruknya tersebut karena pelaku sering terlihat bergonta-ganti pasangan ketika berkencan, kemudian dianggap sebagai wanita gampangan, kehidupan bermasyarakatnya terganggu karena tetangga yang sering memberikan gossip-gosip kurang baik mengenai dirinya, dan juga kehidupan dalam dunia pendidikannya-pun sering terganggu hal itu tidak lain karena penyakit kelamin yang menyulitkannya untuk beraktifitas di sekolah ataupun karena laki-laki yang mengajaknya kencan di waktu sekolah sehingga mengakibatkannya membolos dan halhal tersebut berimbas pada prestasi belajar gadis kupu-kupu abu-abu menurun.

\section{Upaya Penganggulangan Sekolah Terhadap Fenomena Kupu-kupu Abu-abu}

Sekolah merupakan lembaga sosial dalam bidang pendidikan bagi remaja dimana tempat anak remaja diberi pembekalan ilmu pengetahuan serta nilai-nilai sosial masyarakat. Seperti dikatakan Gillin dalam Ahmadi (2007, hlm. 182) meyatakan bahwa "Fungsi pendidikan sekolah ialah penyesuaian diri anak dan stabilisasi masyarakat". Di sekolah anak tidak hanya diajarkan mengenai ilmu pelajaran saja namun lebih dari itu di sekolah anak belajar untuk menjalin kehidupan harmonis dengan orangorang baru, dan sekolah juga bisa menjadi sarana sosialisasi bagi anak remaja untuk pergaulan yang tertata.

Kemudian dikutip dalam Ahmadi (2007, hlm 183) dikatakan bahwa, "Di sekolah anak tidak hanya mempelajari pengetahuan dan keterampilan, melainkan juga sikap, nilai-nilai, dan norma-norma. Sebagian besar sikap dan nilai-nilai itu dipelajari secara informal melalui situasi formal di kelas dan di sekolah". Maka jelas bahwa sekolah merupakan tempat anak menimba ilmu-ilmu baru baik pengetahuan formal maupun informal. Kemudian menyangkut fenomena kupu-kupu abu-abu yang menyangkut pada gadis remaja berstatus pelajar sekolah menawarkan upaya 
penanggulangan diantaranya yaitu dengan cara menetapkan peraturan yang ketat di sekolah sebagai upuya kontrol bagi anak, memberikan pendidikan agama yang baik, menanamkan nilai-nilai kehidupan sosial bermasyarakat dalam lingkungan sekolah, mendekatkan jarak antara peserta didik, guru, maupun karyawankaryawan sekolah untuk menghindari rasa terkekang dari anak atau dalam penanggulangan masalah fenomena kupu-kupu abu-abu dilihat dari aspek sosilogi yaitu dengan cara pemberian mata pelajaran sosiologi dengan menarik dan yang menyangkut permasalah-permasalahan yang ada dalam suatu masyarakat karena mata pelajaran sosiologi dapat menjelaskan sebab dan akibat terhadap seseorang yang melakukan suatu tindak perilaku menyimpang, penyampaian materi tersebut dikemas sedemikian rupa agar tersampai secara ringan, santai dan dipahami peserta didik.

Media pembelajaran dibutuhkan untuk merealisasikan hal tersebut maka dari itu media video sangat ampuh untuk memberi gambaran terhadap anak akibat perilaku menyimpang atau dengan metode penelitian kecil yaitu anak diajak turun langsung untuk observasi mengenai fenomena kupukupu abu-abu tersebut untuk memberikan gambaran jelas mengenai kondisi masyarakat di dunia luas dan bagaimana dampak yang didapatkan ketika melakukan suatu dindak perilaku menyimpang seperti yang dilakukan kupu-kupu abu-abu sehingga anak mengetahui suatu tindakan yang tidak diperbolehkan dalam suatu kehidupan bermasyarakat.

Selanjutnya upaya lain akan dilakukan sekolah ketika ada siswanya sendiri yang termasuk kedalam golongan kupu-kupu abu-abu sekolah akan memberikan pendekatan secara personal dari hati ke hati serta tidak menuduh anak tersebut berasalah karena ketika anak disalahkan ia akan merasakan semakin terpuruk dan enggan mengungkapkan alasannya mengapa melakukan hal buruk tersebut, kemudian cara lain yaitu melalui teman dekatnya karena terkadang pelaku tidak akan mengatakan hal sebenarnya kepada guru bersangkutan atau pihak sekolah maka dari itu informasi dari teman dekat pelaku diperlukan tidak lain untuk mendapatkan kejelasan mengenai pelaku dan tindakan-tindakan tersebut akan dilakukan secara diam-diam agar orang yang tidak bersangkutan dengan masalah ini tidak terlibat karena ditakutkan ketika orang diluar pelaku mengetahuinya maka akan berimbas pada rasa dikucilkannya si pelaku karena dirinya merasa telah dipermalukan di muka umum.

Upaya-upaya yang ditawarkan sekolah tentulah sangat baik jika dilakukan namun dalam upaya yang dilakukan sekolah tersebut dalam keluhnya tetap memerluka pihak lain untuk benar-benar menjadi kontrol sosial bagi kehidupan anak karena sekolah hanya dapat mengawasi anak ketika kegiatan belajar mengajar sedang berlangsung sedangkan kegiatan remaja kupu-kupu abu-abu tersebut terlaksana pada jam-jam sekolah sudah selesai, maka keluarga, dan pihak berwenang dihimbau untuk bisa menjadi kontrol sosial yang baik bagi anak diluar sekolah. Ketika berbagai pihak dapat melakukan hal pengawasan terhadap kehidupan remaja pelajar maka tidak menutup kemungkinan penanaman nilai dan norma dapat berhasil karena norma dan nilai merupakan suatu kontrol sosial yang baik bagi suatu kehidupan. 


\section{SIMPULAN}

Kupu-kupu abu-abu merupakan sebuah fenomena dimana beberapa remaja siswi yang memiliki tindak perilaku menyimpang, perilaku menyimpang yang dilakukan kupukupu abu-abu adalah melakukan hubungan seks diluar nikah atas dasar kesenangan semata. Dalam kegiatan yang dilakukan kupu-kupu abu-abu ini sekilas nampak sama seperti WTS (wanita tuna susila) di lokalisasi yang bisa melakukan hubungan seks secara bebas dengan siapa saja akan tetapi kupu-kupu abu-abu disini melakukan hubungan seks secara bebas bukan berdasarkan materi atau uang namun lebih ke pemuasan diri pribadi akan kebutuhan seksualnya yang harus dipenuhi.

Para remaja siswi kupu-kupu abuabu enggan disamakan dengan pelacur karena menurut pengakuannya dalam berhubungan seks secara bebas mereka tetap memiliki syarat pada para laki-laki yang ingin mengencaninya dan salah satu syarat yang harus dipenuhi laki-laki itu ialah harus memiliki wajah yang tampan dan berpenampilan menarik jadi ketika syarat itu tidak dipenuhi laki-laki yang ingin mengencaninya maka gadis kupu-kupu abu-abu ini menolak untuk berkencan. Mereka para kupu-kupu abu-abu tidak menjajakan diri seperti WTS pada umumnya dan tidak memiliki tempat tertentu untuk melakukan hubungan seks, dan tempat dalam melakukan hubungan seks biasanya disediakan oleh laki-laki yang sedang mengencaninya tempat itu biasanya di motel-motel, kost-kostan, dan rumah laki-laki itu sendiri.

Karena para pelaku kupu-kupu abu-abu ini tidak memiki tempat layaknya WTS di lokalisasi yang sudah memiliki rumah-rumah bordil dalam menjajakan

dirinnya

dan mempermudah para laki-laki hidung belang yang ingin mencarinya sebagai pemberi jasa pemuas nafsu seks lakilaki hidung belang tersebut. Maka untuk kupu-kupu abu-abu sendiri tidak bisa ditemukan semudah itu karena mereka tidak menjajakan diri dan tidak mendeklarasikan bahwa dirinya adalah wanita yang bisa 'dipakai' oleh semua orang seperti pelaku prostitusi di lokalisasi pada umumnya oleh karena itu keberadaan kupu-kupu abu-abu sendiri sulit untuk diketahui baik bagi masyarakat luas atau bahkan untuk laki-laki hidung belang sendiri sebagai laki-laki yang ingin mengencaninya namun bukan berarti tidak bisa diketahui sama sekali akan keberadaan kupu-kupu abu-abu ini karena keberadaannya dapat diketahui oleh laki-laki hidung belang yang sudah melakukan kencan bersama kupu-kupu abu-abu tersebut atau dengan kata lain karena keberadaan kupu-kupu abu-abu ini sangatlah terselubung maka untuk bisa mendapatkannya hanya bisa dengan cara mencari laki-laki hidung belang yang pernah mengencaninya dan memintanya untuk menghubungkannya dengan kupukupu abu-abu karena apabila tidak menggunakan cara seperti itu kupukupu abu-abu sangat sulit untuk ditemukan.

\section{DAFTAR PUSTAKA}

Ahmadi, Abu. (2007). Sosiologi Pendidikan. Jakarta: RINEKA CIPTA.

Anwar, dan Adang. (2010). Kriminologi. Jakata: PT. Refika Aditana.

Bungin, B. (2012). Penelitian Kualitatif. Jakarta: Prenada Media Group.

Creswell, John W. (2010). Pendekatan Kualitatif, Kuantitatif, dan Mixed. Yogyakarta: Pustaka Pelajar. 
Kartono, Kartini. (1981). Patologi Sosial Jilid 1. Depok: Raja Grafindo Persada.

Soekanto, Soerjono. (1982). Sosiologi Suatu Pengantar. Jakarta: Rajawali Pers.

Willis, S. (2012). Remaja dan Masalahnya. Bandung: Alfabeta 